\title{
Postmenopozal Kadınlarda Fiziksel Aktiflik Durumu ile Antropometrik Ölçümler ve Vücut Kompozisyonu Özelliklerinin İlişkisi
}

\section{The Relationship Between Physical Activity Status and Anthropometric Measurements and Body Composition Features in Postmenopausal Women}

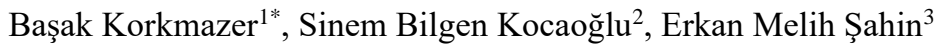 \\ ${ }^{1}$ Başakş̧ehir Çam ve Sakura Şehir Hastanesi Aile Hekimliği Kliniği, İstanbul, Türkiye \\ ${ }^{2}$ Eceabat İlçe Devlet Hastanesi Aile Hekimi Uzmanı, Çanakkale, Türkiye \\ ${ }^{3}$ Çanakkele Onsekiz Mart Üniversitesi Tıp Fakültesi Aile Hekimliği AD, Çanakkale, Türkiye \\ e-mail: basakkorkmazer@gmail.com, sinembilgenkocaoğlu@gmail.com,emsahin@yahoo.com \\ ORCID: 0000-0003-2977-0693 \\ ORCID: 0000-0001-7671-688X \\ ORCID: 0000-0003-1520-8464 \\ *Sorumlu yazar/ Corresponding Author: Başak Korkmazer
}

Gönderim Tarihi / Received: 06.07.2020

Kabul Tarihi / Accepted: 23.11.2020

DOI: $10.34087 /$ cbusbed. 764758

\begin{abstract}
Giriş ve Amaç: Menopoz geçişi normal yaşlanma sürecinin bir parçası olmasına rağmen devamındaki değişiklikler kadınların sağlık-risk profilini etkilemektedir ve bu etki, birçok faktöre bağlıdır. Bu çalışmanın amacı postmenopozal kadınlarda fiziksel aktiflik durumu ile antropometrik ve vücut kompozisyonu özelliklerinin ilişkisini araştırmaktır.

Gereç ve Yöntemler: Kesitsel nitelikteki bu çalışma Çanakkale Onsekiz Mart Üniversitesi Uygulama ve Araştırma Hastanesi kayıtlarında bulunan 45 yaş üstü 95 postmenopozal kadınla yürütülmüştür. Veriler araştırmacılar tarafından hazırlanan sosyodemografik veri anketi, Uluslararası Fiziksel Aktivite Testi-kısa formu, antropometrik ölçümler ve biyoempedans yoluyla vücut kompozisyonunun ölçümü ile toplanmıştır.

Bulgular: Yaş ortalaması 61,7 7,2 [47 - 77] olan ve ortalama 14,6 \pm 7,4 [1 - 35] yıldır postmenopozal dönemde olan 95 katılımcının ortalama ağırlığ $74,0 \pm 13,6$ [46,6 - 110,0] kg, boyu 155,9 $\pm 6,0$ [141 - 171] cm idi. Menopoz sonrası geçen süre ile vücut ağırlığ 1 arasında anlamlı negatif korelasyon mevcuttu. Yaş ve menapoz üzerinden geçen süre ile yağsız kitle arasında anlamlı negatif korelasyon mevcuttu. Katılımcıların IPAQ skorları ile yaş arasında korelasyon yoktu. Katılımcıların vücut ağırlığı, bel çevresi, kalça çevresi ortalamaları IPAQ Kategori I'de Kategori II'dekinden anlamlı yüksekti. Katılımcıların biyoempedans ölçümlerinden yağ kitlesi, yağ yüzdesi ve yağsız kitlesi ortalamaları IPAQ Kategori I'de, Kategori II'den anlamlı yüksekti. Ortalama SMI, ASMI, ALMI hesaplamaları IPAQ kategorileri arasında anlamlı farklı değildi.

Sonuç: Menopoz sonrası hormon kullanımının kalp hastalıklarına karşı korunmasındaki yetersizliği göz önüne alındığında, sağlığın korunmasında egzersizin rolü önemlidir. Çalışmamızda da gösterdiğimiz üzere menopoz süresi veya yaşın bir önemi olmaksızın fiziksel aktivitenin hayata entegre edilmesi düşük bel çevresi, yağ kitlesi, yağ yüzdesi ve yağsız kitlede artış ile karakterizedir.
\end{abstract}

Anahtar kelimeler: Antropometrik ölçümler, Biyoimpedans, Fizik aktivite, IPAQ, Postmenopoz.

\section{Abstract}

Objective Although the transition to menopause is a part of the normal aging process, changes occurring at this stage of life, affect the health-risk profile of women. This effect depends on many factors. The aim of this study is to investigate the relationship between physical activity and anthropometric and bioimpedance characteristics in postmenopausal women.

Material and Methods: This cross-sectional study was conducted with 95 postmenopausal women over 45 years of age who were chosen in the records of Çanakkale Onsekiz Mart University Practice and Research Hospital. The data were collected by socio-demographic data survey prepared by the researchers, International Physical Activity Testshort form, anthropometric measurements and measurement of body composition. 
Results: The average weight of 95 participants with a mean age of $61.7 \pm 7.2[47-77]$ and an average of $14.6 \pm 7.4$ $[1$ - 35] years in the postmenopausal period was $74.0 \pm 13.6[46.6-110,0] \mathrm{kg}$, height was $155.9 \pm 6.0[141-171] \mathrm{cm}$. There was a statistically negative correlation between the period after menopause and body weight. There was a negative correlation between age and time over menopause and lean mass. There was no correlation between the participants' IPAQ scores and age. The mean body weight, waist circumference, hip circumference of the participants were significantly higher in IPAQ Category I than in Category II. The fat mass, fat percentage and lean mass averages of the participants' bioimpedance measurements were significantly higher in IPAQ Category I than Category II. Average SMI, ASMI, ALMI calculations were not significantly different between IPAQ categories.

Conclusion: Given the insufficiency of post-menopausal hormone use in protecting against heart disease, the role of exercise in health protection is important. As we have shown in our study, the integration of physical activity into life, regardless of menopause duration or age, is characterized by low waist circumference, fat mass, fat percentage and an increase in lean mass.

Keywords: Anthropometric measurements, Bioimpedance, IPAQ, Physical activity, Postmenopause.

1. Giriş
Önümüzdeki 50 yıl için öngörülen demografik
değişiklikler, dünya genelinde, yaşlıların sayısının
artmasıyla birlikte metabolizma ile ilişkili hastalıkların
sıklığının da artacağını göstermektedir [1]. Kadınların
yaşamlarının en kritik aşamalarından biri de
menopozdur. Menopoz
değişikliklere ek olarak, en az 12 ay içinde adet dönemi yaşamamış bir kadın, postmenopozal dönemde olarak kabul edilir. İlerleyen yaş grubundaki kadın popülasyonu ele alındığında büyük çoğunluğunu postmenapozal kadınların oluşturacağı unutulmamalıdır. Menopoz, kemik mineral dansisitesi, bazal metabolizma hızı ve yağsız kütlenin azalmasının yanı sıra, vücut yağ oranında artışa neden olabilecek azalmış serum östrojen seviyeleri ile ilişkilidir [2]. Menopoz geçişi her yıl 1.5 milyon kadın tarafından tecrübe edilir ve sıklıkla vazomotor semptomlar, vajinal kuruluk, azalmış libido, uykusuzluk, yorgunluk ve eklem ağrısı dahil olmak üzere zahmetli semptomları da beraberinde getirir [3].

Postmenopozal dönemde gelişen değişiklikler kadınların yaşam kalitesini olumsuz yönde etkiler. Menopozun ortalama olarak 50'li yaşlarda başladığı varsayıldığında, kadınlar yaşamlarının üçte birini postmenopozal dönemde maruz kaldıkları patolojik değişikliklerle geçirirler [4]. Menopoz geçişi normal yaşlanma sürecinin bir parçası olmasına rağmen, yaşamın bu aşamasında meydana gelen hormonal değişiklikler kadınların sağlıkrisk profilini de değiştirir [5]. Bununla birlikte, yaşam kalitesinin menopoz sırasında etkilenip etkilenmediği, semptomlar ve diğer fiziksel sağlık, psikososyal durum, yaşam tarzı ve bağlamsal değişkenler gibi birçok faktöre bağlıdır [6]. Fizyolojik bir olay olarak menopozda kadınların yaşam kalitesini etkileyen bazı değişiklikler gerçekleşir. $\mathrm{Bu}$ dönemde menopoz semptomlarını azaltmak ve yaşam kalitesini iyileştirmek için hormon tedavisi ve farmakolojik olmayan tedaviler gibi çeşitli önlemler önerilmektedir [7].

Önceki araştırmalar, şehirlerde yaşayan postmenopozal kadınların kırsal kesimde yaşamakta olan yaşıtlarına kıyasla daha hareketsiz olduğunu göstermiştir; bu grupta dengesiz ve tek tip beslenme nedeniyle kilo alımı da yaygın olarak rastlanan bir olgudur [8]. Menopozda yaşa, hareketsizliğe ve kullanılan hormon ilaçlarına bağlı olarak gelişen kilo artışı; düzenli egzersiz ve kalori kısıtlamasıyla en aza indirilebilir [9]. Ek olarak yaşlı yetişkinlerde yüksek yağ kütlesi, daha düşük fiziksel işlev ve daha yüksek bağımlılık sıklığının bir göstergesidir [10].

Erkeklerle karşılaştırıldığında, kadınlar vücut yağ dağılımı modellemesi için daha geniş bir olasılık yelpazesine sahiptir [11]. Kadınlarda vücut yağ dağılımı paterninin çeşitliliği, antropometrik ölçümlerle vücut yağ yüzdesi tahmininin genelleştirilmesini karmaşıklaştırabilir ve belki de sınırlayabilir. Ek olarak, fazla kilolu olarak sinıflandırılan (Beden kitle indeksi (BKI) $\geq 25,0)$ kadınların yaygınlığı, orijinal regresyon denklemlerinin birçoğunun üretilmesinden bu yana yaklaşık $\% 9$ oranında artmıştır [12]. Vücut kompozisyonunu değerlendirmek ve yağ dokusunun göreceli miktarlarını belirlemek için manyetik rezonans görüntüleme ve çift enerjili X-1̧sını absorpsiyometrisi gibi kriter yöntemler mevcuttur ancak bu yöntemler pahalı, invazif ve zaman alıcıdır. Buna karşılık biyoelektrik empedans analizi vücut yağ dağılımı tahminlerini elde etmek ve artan sağlık riski altında olanları tanımlamak için nispeten düşük maliyetli ve basit bir yöntem olarak kullanılagelmektedir [13].

Fiziksel aktivite hakkındaki literatürde, çeşitli popülasyonlarda egzersiz ve fiziksel aktivite katılımının psikolojik refah ve yaşam kalitesi üzerindeki sürekli olumlu etkileri vurgulansa da, menopoz sonrası dönemdeki kadınların özel bir grup olarak değerlendirilmesi önemlidir. $\mathrm{Bu}$ çalışmanın amacı postmenopozal kadınlarda fiziksel aktiflik durumu ile antropometrik ve vücut kompozisyonu özelliklerinin ilişkisini araştırmaktır.

\section{Materyal ve Metot}

\subsection{Evren ve Örneklem}

Çalışma Çanakkale Onsekiz Mart Üniversitesi Uygulama ve Araştırma Hastanesi kayıtlarında bulunan 45 yaş üstü postmenopozal kadınlarda yürütülmüştür. Son 12 aydır amenore öyküsü olan hastalar postmenopozal olarak kabul edilerek, hastane kayıtlarından belirlenen 957 kişiden 416 kişiye ulaşılabilmiş, onam veren 95 postmenopozal kadınla çalışma yürütülmüştür.

\subsection{Veri Toplama Araçları}

Veriler araştırmacılar tarafından hazırlanan sosyodemografik veri anketi, Uluslararası Fiziksel Aktivite Testi-kısa formu (IPAQ), antropometrik 
ölçümler ve biyoempedans yoluyla vücut kompozisyonunun ölçümü ile toplanmıştır.

Katılımcıların fiziksel aktivite düzeyini belirlemek için IPAQ testi-kısa form kullanılmıştır [14]. Ölçekte yoğun aktiviteler, orta yoğunlukta aktiviteler ve yürüyüş, süre ve frekans açısından sorgulanmaktadır. Oturma süresi ise ayrıca sorgulanıp değerlendirilmektedir. Değerlendirmeyi kolaylaştırmak için "Continious" skorlaması kullanılmaktadır. Continious skorlamasında; şiddetli fiziksel aktivite 8 metabolik eşdeğer (MET), orta fiziksel aktivite 4 MET, yürüme 3,3 MET olup bu değerlerin süre (günde kaç dakika yapıldığı) ve frekansla (haftada kaç gün tekrarlandığı) çarpımı ile skor elde edilmiş olur. Değerler $60 \mathrm{~kg}$ bireye göre hesaplanmış olup formüle "kilo/60"çarpanı eklenebilir. Elde edilen IPAQ continious skoruna göre bireyler inaktif, düşük seviyede aktif, yeterli seviyede aktif olarak sınıflanırlar [15]. I kategori (inaktif olanlar): <600 MET-dk.g/hf; II kategori (düşük seviyede aktif olanlar): 600 - 3000 METdk.g/hf; III kategori (yeterli seviyede aktif olanlar): >3000 MET-dk.g/hf olarak sinıflandırılmaktadır.

Hastaların kilo ve vücut kompozisyonunun ölçümü bioelektriksel empedans analiz cihazı ile yapılmıştır. Biyoelektrik empedans analizi cihazı vücut dokularının az miktarda zararsız elektrik akımına maruz bırakılarak, farklı dirençlerin ölçülmesi ile hesaplama yapmaktadır. Hastalar ölçüm öncesinde 12 saat boyunca aç durmaları, alkol tüketmemeleri ve yoğun egzersiz uygulamamaları konusunda uyarılmışlardır. Çalışmamızda kullandığımız "Tanita Body Composition Analyzer Tanita BC - 418 Japan” BIA geçerlilik çalışmaları yapılmış olup, ölçümler üreticinin talimatlarına göre yapılmıştır [16].

Çalışmamızda Sarkopeni Avrupa Çalışma Grubu tarafından biyoimpedans yöntemi ile kas tahmini yöntemlerinden sayllan, toplam tahmini kas kitlesinin yüksekliğin metre cinsinden karesine bölünmesi ile elde edilen değer İskelet Kas Endeksi (SMI, Skeletal Muscle Index) olarak; Baumgarte ve arkadaşlarının dört ekstremitenin kas kitlesi toplamını ASM (Appendiküler skeletal Muscle Mass) olarak tanımlayarak bu değeri yüksekliğin metre cinsinden karesine bölünmesi ile hesapladıkları değer ASMI (Appendiküler Skeletal Muscle Index) olarak; Newman ve arkadaşları yağsız kitleyi yüksekliğin metre cinsinden karesine bölerek yağsız kitleyi vücut büyüklüğüne ayarladıkları değer ALMI (Appendiküler Lean Mass Index) olarak belirtilmiş ve kullanılmıştır [17]. Kompozisyon değerleri [yağ kitlesi (kg), yağ Yüzdesi (\%), yağsız kitle (kg), SMI $\left.\left(\mathrm{kg} / \mathrm{m}^{2}\right)\right]$ hesaplanmıştır.

\section{3 İzin ve Onamlar}

Çalışmaya başlamadan önce ÇOMÜ Tıp Fakültesi Klinik Araştırmalar Etik Kurulu onayı (27/2016-E.99849) alınmıştır. Çalışmaya katılımı kabul eden hastalara çalışma hakkında sözel bilgi verilerek yazılı onamları alınmıştır.

\subsection{Istatistiksel Analiz}

Verilerin dijital ortama aktarılmasının ardından veri düzeltme işlemleri yürütüldü. Kategorik değişkenler için sayı ve yüzde sürekli değişkenler için ortalama, standart sapma, en düşük ve en yüksek değerler verildi. Örneklem sayısı 30'dan büyük olduğundan santral limit teoremine dayanılarak parametrik testlerde normal dağ 11 lım varsayımı ihmal edildi [18]. Yeterli katılımcı sayıs1 bulunmayan IPAQ kategori III grubu bazı istatistiksel analizlerde hariç bırakılarak iki grup karşılaştırması yapıldı. Ortalama karşılaştırmaları için değişken özellikleri uyarınca bağımsız örneklem $t$ testi veya ANOVA sürekli değişkenlerin karşılaştırılmasında Pearson korelasyon testi uyguland. Tüm istatistik analizlerde test sabiti ve mutlak $\mathrm{p}$ değeri ifade edildi, genel anlamlılık sınırı olarak $\mathrm{p}<0,05$ kabul edildi.

\section{Bulgular ve Tartışma}

\subsection{Bulgular}

Araştırmaya katılan 95 postmenopozal kadının sosyodemografik özellikleri ve alışkanlıkları Tablo 1'de verilmiştir.

Tablo 1. Sosyodemografik özellikler ve alışkanlıklar

\begin{tabular}{|l|l|l|}
\hline \multicolumn{1}{|l|}{ Yaş } & & $61,7 \pm 7,2[47-77]$ \\
\hline Menopoz süresi (yıl) & & $14,6 \pm 7,4[1-35]$ \\
\hline Eğitim süresi (yıl) & Evli & $8,1 \pm 4,3[0-16]$ \\
\hline Medeni durum & Bekar, Dul, Boşanmış & $74(\% 77,9)$ \\
\hline Çalışma durumu & Aktif çalışan & $21(\% 22,1)$ \\
\hline & Emekli & $8(\% 8,4)$ \\
\hline \multirow{2}{*}{ Sigara kullanımı } & Çalışmayan & $38(\% 40,0)$ \\
\hline & Hiç içmemiş & $49(\% 51,6)$ \\
\hline & Birakmış & $70(\% 73,7)$ \\
\hline & İçiyor & $16(\% 16,8)$ \\
\hline & & $9(\% 9,5)$ \\
\hline
\end{tabular}


Katılımcıların ortalama ağırlığ $14,0 \pm 13,6$ [46,6 - 110] $\mathrm{kg}$, boyu 155,9 $\pm 6,0$ [141 - 171] cm idi. BKİ ortalamaları $30,6 \pm 5,9[19,5-54,7] \mathrm{kg} / \mathrm{m}^{2}$ olarak hesapland 1 . Katılımcıların ortalama bel çevresi 97,3 $\pm 12,7$ [70 - 42] $\mathrm{cm}$, kalça çevresi 110,5 $\pm 11,7$ [85 - 154] cm, bel-kalça oran1 0,88 $\pm 0,06[0,72-1,04]$ idi.

Katılımcıların yaşı ile vücut ağırlığı veya BKİleri arasinda korelasyon yoktu (sirasiyla $\mathrm{r}=-0,093 ; \mathrm{p}=0,382$, $\mathrm{r}=0,048 ; \mathrm{p}=0,642)$. Yaş ile bel çevresi $(\mathrm{r}=0,216 ; \mathrm{p}=0,036)$ ve bel-kalça oranı $(r=0,361 ; p<0,001)$ arasında anlamlı pozitif korelasyon mevcutken, kalça çevresi arasında korelasyon yoktu $(\mathrm{r}=0,030 ; \mathrm{p}=0,769)$.

Menopoz sonrası geçen süre ile vücut ağırlığı arasında anlamlı negatif korelasyon mevcutken ( $\mathrm{r}=-0,215$; $\mathrm{p}=0,037)$, BKİ ile arasında anlamlı korelasyon yoktu $(\mathrm{r}=$ 0,$050 ; \mathrm{p}=0,633$ ).

Katılımcıların menopoz üzerinden geçen süre ile $\mathrm{BKO}$ arasında anlamlı pozitif korelasyon mevcuttu ( $\mathrm{r}=0,235$; $\mathrm{p}=0,022)$, bel çevresi $(\mathrm{r}=0,025 \mathrm{p}=0,811)$ ve kalça çevresi arasında korelasyon yoktu $(\mathrm{r}=-0,123 ; \mathrm{p}=0,237)$.

Katılımcıların biyoempedans ölçümlerine göre ortalama yağ kitlesi 29,1 $\pm 9,3$ [10,7 - 60] kg, ortalama yağ yüzdesi $\% 38,4 \pm 6,4[20,3-55,1]$, ortalama yağsız kitlesi 44,9 \pm $5,6[33,1$ - 60,2] kg idi. Katılımciların ortalama SMI değeri $17,6 \pm 2,1[13,8-23,3] \mathrm{kg} / \mathrm{m}^{2}$, ortalama ALMI değeri $8,1 \pm 1,1[6,2-11,2] \mathrm{kg} / \mathrm{m}^{2}$, ortalama ASMI değeri $7,7 \pm 1,0[5,8-10,5] \mathrm{kg} / \mathrm{m}^{2}$ idi.

Yaş ile yağ kitlesi $(\mathrm{r}=-0,011 \mathrm{p}=0,916)$ ve yağ yüzdesi $(\mathrm{r}=0,113 \mathrm{p}=0,276)$ arasında korelasyon yokken, yağsız kitle arasinda anlamlı negatif korelasyon mevcuttu ( $\mathrm{r}=$ $0,203 \mathrm{p}=0,048)$.

Katılımcıların menopoz üzerinden geçen süre ile yağ kitlesi ( $r=-0,122 \mathrm{p}=0,242)$ ve yağ yüzdesi $(r=0,035$; $\mathrm{p}=0,738$ ) arasında korelasyon yokken, yağsı kitle arasinda anlamlı negatif korelasyon mevcuttu $(\mathrm{r}=-0,320$; $\mathrm{p}=0,002)$.

SMI, ALMI ve ASMI değerleri ile yaş (sırasıyla $\mathrm{r}=$ 0,$036 ; \mathrm{p}=0,726, \mathrm{r}=-0,042 ; \mathrm{p}=0,686, \mathrm{r}=-0,041 ; \mathrm{p}=0,693$ ) veya menopoz üzerinden geçen süre (sırasıyla $\mathrm{r}=-0,130$ $\mathrm{p}=0,210 ; \mathrm{r}=-0,120 \mathrm{p}=0,250 ; \mathrm{r}=-0,125 ; \mathrm{p}=0,231)$ arasinda korelasyon yoktu.
Katılımcıların oturarak geçirdiklerini beyan ettikleri süre günde ortalama $5,4 \pm 2,8[0-13]$ saat idi. IPAQ continious skor ortalamasi $611,9 \pm 847,2$ [0 - 4851] MET-dk-gün/hafta olarak hesaplandi. Continious skorlarına göre sinıflamada Kategori I'de $66(\% 69,5)$ katılımc1, Kategori II'de $27(\% 28,4)$ katılımc1 ve Kategori III'te $2(\% 2,1)$ katılımc1 mevcuttu.

Katılımcıların IPAQ continious skorları ile yaş arasında korelasyon yoktu $(\mathrm{r}=-0,058 ; \mathrm{p}=0,578)$. Sigara içen katılımcı sayısı IPAQ Kategori I'de $5(\% 7,6)$, IPAQ Kategori II'de 3 (\%11,1) iken; sigarayı bırakan $8(\% 12,1)$ kişi IPAQ Kategori I'de, 8 (\%29,6) kişi Kategori II'de idi. Hiç sigara içmemiş kişi sayısı IPAQ I. kategoride 53 $(\% 80,3)$, IPAQ Kategori II'de $16(\% 27,3)$ idi. IPAQ Kategori III'te yer alan 2 katılımcıdan biri hiç sigara içmemiş, biri halen sigara içiyordu. IPAQ kategorileri arasında sigara içme durumu arasında fark yoktu $\left(X^{2}=8,933 ; p=0,063\right)$.

IPAQ continious skorları ile vücut ağırlığı ve BKİ arasinda korelasyon yoktu (sirasiyla $r=-0,168 ; p=0,103$, $\mathrm{r}=-0,080 ; \mathrm{p}=0,440)$. IPAQ continious skorları ile bel çevresi, kalça çevresi ve bel-kalça oranı arasında korelasyon yoktu (sirasiyla $\mathrm{r}=-0,162 ; \mathrm{p}=0,117, \mathrm{r}=-0,103$; $\mathrm{p}=0,320, \mathrm{r}=-0,134 ; \mathrm{p}=0,194)$. IPAQ continious skorlar1 ile yağ kitlesi, yağ yüzdesi ve yağsız kitle arasında korelasyon yoktu ( sirasiyla $\mathrm{r}=-0,132 ; \mathrm{p}=0,203, \mathrm{r}=-0,164$; $\mathrm{p}=0,113, \mathrm{r}=-0,184 ; \mathrm{p}=0,075)$. IPAQ continious skorlar1 ile SMI, ALMI, ASMI değerleri arasında korelasyon yoktu (sirasiyla $\mathrm{r}=-0,067 ; \mathrm{p}=0,516, \mathrm{r}=-0,064 ; \mathrm{p}=0,536$, $\mathrm{r}=-0,065 ; \mathrm{p}=0,529)$.

Katılımcıların antropometrik ölçümlerinin IPAQ gruplarındaki durumları Tablo 2'de verilmiştir. Katılımcıların IPAQ Kategori I'de vücut ağırlığg 1 (76,5 \pm $12,9 \mathrm{~kg})$, bel çevresi $(99,2 \pm 12,7 \mathrm{~cm})$, kalça çevresi $(112,3 \pm 10,6 \mathrm{~cm})$ IPAQ Kategori II'deki ortalamalardan (sirasiyla 68,4 $\pm 13,7 \mathrm{~kg}, 93,3 \pm 10,8 \mathrm{~cm}, 106,6 \pm 13,3$ ) anlamlı yüksekti (sırasıyla $\mathrm{t}=2,713 ; \mathrm{p}=0,008, \mathrm{t}=2,123$; $\mathrm{p}=0,036, \mathrm{t}=2,200 ; \mathrm{p}=0,030)$. IPAQ Kategori I ve II arasında BMI ve bel-kalça oranı ortalamaları arasında anlamlı fark yoktu (sirasiyla $\mathrm{t}=1,821 ; \mathrm{p}=0,072, \mathrm{t}=0,489$; $\mathrm{p}=0,626)$.

Tablo 2. IPAQ gruplarında antropometrik ölçümler

\begin{tabular}{|c|c|c|c|}
\hline & $\begin{array}{c}\text { IPAQ } \\
\text { Kategori I } \\
(n=66)\end{array}$ & $\begin{array}{c}\text { IPAQ } \\
\text { Kategori II } \\
(\mathbf{n = 2 7})\end{array}$ & İstatistik \\
\hline Vücut ağırlığı (kg) & $\begin{array}{c}76,5 \pm 12,8 \\
{[46,6-110,0]}\end{array}$ & $\begin{array}{c}68,4 \pm 13,7 \\
{[46,8-108,8]}\end{array}$ & $\begin{array}{l}\mathrm{t}=2,713 \\
\mathrm{p}=0,008\end{array}$ \\
\hline BKİ (kg/m2) & $\begin{array}{c}31,3 \pm 5,3 \\
{[21,3-47,8]}\end{array}$ & $\begin{array}{c}28,9 \pm 7,1 \\
{[19,5,-54,7]}\end{array}$ & $\begin{array}{l}\mathrm{t}=1,821 \\
\mathrm{p}=0,072\end{array}$ \\
\hline Bel çevresi $(\mathrm{cm})$ & $\begin{array}{c}99,2 \pm 12,7 \\
{[72-142]}\end{array}$ & $\begin{array}{c}93,3 \pm 10,8 \\
{[75-122]}\end{array}$ & $\begin{array}{l}\mathrm{t}=2,123 \\
\mathrm{p}=0,036\end{array}$ \\
\hline Kalça çevresi (cm) & $\begin{array}{c}112,3 \pm 10,6 \\
{[85-138]}\end{array}$ & $\begin{array}{c}93,3 \pm 10,8 \\
{[75-122]}\end{array}$ & $\begin{array}{l}\mathrm{t}=2,200 \\
\mathrm{p}=0,030\end{array}$ \\
\hline Bel-kalça oranı & $\begin{array}{c}0,88 \pm 0,68 \\
{[0,72-1,04]}\end{array}$ & $\begin{array}{c}0,88 \pm 0,43 \\
{[0,79-0,97]}\end{array}$ & $\begin{array}{l}\mathrm{t}=0,489 \\
\mathrm{p}=0,626\end{array}$ \\
\hline
\end{tabular}

$*$ t testi, $\mathrm{p}<0,05$ 
Katılımcıların biyoempedans ölçümlerinin IPAQ gruplarındaki durumları Tablo 3'te verilmiştir. Katılımcıların IPAQ Kategori I'de ortalama yağ kitlesi $(30,8 \pm 8,4 \mathrm{~kg})$, ortalama yağ yüzdesi $(\% 39,7 \pm 5,2)$, ortalama yağsız kitlesi $(45,6 \pm 5,5 \mathrm{~kg})$ IPAQ Kategori II'deki ortalamalardan (sırasiyla $25,4 \pm 10,1 \mathrm{~kg}, \% 35,9$ $\pm 7,6,43,0 \pm 5,4 \mathrm{~kg}$ ) anlamlı yüksekti (sırasıyla $\mathrm{t}=2,622$; $\mathrm{p}=0,010, \mathrm{t}=2,783 ; \mathrm{p}=0,007, \mathrm{t}=2,065 ; \mathrm{p}=0,042)$. IPAQ Kategori I ve II arasında SMI, ALMI ve ASMI değer ortalamaları arasında anlamlı fark yoktu (sirasiyla $\mathrm{t}=1,113 ; \mathrm{p}=0,260, \mathrm{t}=1,455 ; \mathrm{p}=0,149, \mathrm{t}=1,451 ; \mathrm{p}=0,150)$.

Tablo 3. IPAQ gruplarında biyoimpedans ölçümler

\begin{tabular}{|c|c|c|c|}
\hline 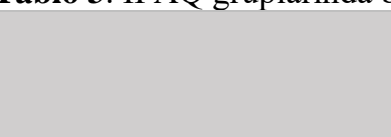 & $\begin{array}{c}\text { IPAQ } \\
\text { Kategori I } \\
(n=66)\end{array}$ & $\begin{array}{c}\text { IPAQ } \\
\text { Kategori II } \\
(\mathbf{n = 2 7 )}\end{array}$ & İstatistik \\
\hline $\begin{array}{l}\text { Ortalama yağ kitlesi } \\
(\mathrm{kg})\end{array}$ & $\begin{array}{c}30,8 \pm 8,4 \\
{[13,4-54,0}\end{array}$ & $\begin{array}{c}25,4 \pm 10,1 \\
{[11,1-60,0]}\end{array}$ & $\begin{array}{l}\mathrm{t}=2,622 \\
\mathrm{p}=0,010\end{array}$ \\
\hline $\begin{array}{l}\text { Ortalama yağ yüzdesi } \\
(\%)\end{array}$ & $\begin{array}{c}39,7 \pm 5,2 \\
{[28,8-51,7]}\end{array}$ & $\begin{array}{c}35,9 \pm 7,6 \\
{[20,3-55,1]}\end{array}$ & $\begin{array}{l}\mathrm{t}=2,783 \\
\mathrm{p}=0,007\end{array}$ \\
\hline $\begin{array}{l}\text { Ortalama yağsız kitle } \\
(\mathrm{kg})\end{array}$ & $\begin{array}{c}45,6 \pm 5,5 \\
{[33,1-60,2]}\end{array}$ & $\begin{array}{c}43,0 \pm 5,4 \\
{[33,8-53,7]}\end{array}$ & $\begin{array}{l}\mathrm{t}=2,065 \\
\mathrm{p}=0,042\end{array}$ \\
\hline Ortalama SMI $\left(\mathrm{kg} / \mathrm{m}^{2}\right)$ & $\begin{array}{c}17,7 \pm 2,0 \\
{[13,8-22,9]}\end{array}$ & $\begin{array}{c}17,2 \pm 2,3 \\
{[14,1-23,3]}\end{array}$ & $\begin{array}{l}\mathrm{t}=1,113 \\
\mathrm{p}=0,260\end{array}$ \\
\hline Ortalama ALMI (kg/m²) & $\begin{array}{c}8,3 \pm 1,0 \\
{[6,3-10,8]}\end{array}$ & $\begin{array}{c}7,9 \pm 1,3 \\
{[6,2-11,2]}\end{array}$ & $\begin{array}{l}\mathrm{t}=1,455 \\
\mathrm{p}=0,149\end{array}$ \\
\hline Ortalama ASMI (kg/m²) & $\begin{array}{c}7,8 \pm 0,9 \\
{[6,0-10,2]}\end{array}$ & $\begin{array}{c}7,4 \pm 1,2 \\
{[5,8-10,5]}\end{array}$ & $\begin{array}{l}\mathrm{t}=1,451 \\
\mathrm{p}=0,150\end{array}$ \\
\hline
\end{tabular}

$* t$ testi, $\mathrm{p}<0,05$

\subsection{Tartısma}

Obezite prevalansının artması, özellikle yaşlı erişkinlerde önemli bir halk sağlığı sorunu olarak ortaya çıkmaktadır [19]. Doksan beş katılımcılı, postmenopozal kadınlarda fiziksel aktiflik durumu ile antropometrik ve biyoimpedans özelliklerin ilişkisini değerlendirdiğimiz çalışmamızda, daha fazla fiziksel aktivite daha düşük kilo artış1, daha düşük bel çevresi ölçümü, daha düşük vücut yağ kitlesi ve yüzdesi ile ilişskiliydi; ancak fiziksel aktivite düzeyleri ile BKİ arasında anlamlı farklılık saptanmamıştı.

Genel popülasyonda BKİ'deki değişimin büyük ölçüde vücut yağ oranındaki farklılıklardan kaynaklandı̆̆ bilinmektedir, ancak tanım gereği BKİ, yağ ve yağsız vücut kütlesini bir arada içerir ve bu nedenle sağlık sonuçları ile ilişkilerinde yağ ve yağsız kütlenin rollerin çözmek zordur. Bazı kohort çalışmaları daha fazla fiziksel aktivitenin, BKİ etkisi kaldırıldıktan sonra bile, menopoz sonrası meme kanseri riskinde azalma ile ilişkili olduğunu göstermiştir ve bu bulgu genellikle fiziksel aktivitenin menopoz sonrası meme kanseri için bir risk faktörü olarak yağlanmadan bağımsız olduğuna dair kanıt olarak kabul edilmektedir [20]. Fiziksel aktivite ve yağlanmanın bir çok hastalık riski üzerindeki olası etkilerini ortadan kaldırmak için, gelecekteki araştırmalar daha spesifik yağlanma önlemlerine odaklanmalıdir.

Fiziksel aktivite ve yağlanma ile ilgili daha önceki gözlemsel çalışmalar, yüksek yoğunluklu fiziksel aktivitenin düşük prevalansı, düşük yoğunluklu aktivite ile ilişkili ölçüm hatası ve değerlendirmenin uygun olmayan zaman çerçevesi nedeniyle eleştirilmiştir [21]. Çalışmamıza dahil olan postmenopozal kadınların IPAQ gruplarına göre dağılımları değerlendirildiğinde, yeterli seviyede (Kategori III) egzersiz yapan kadın sayısının azlığı nedeniyle değerlendirmeler inaktif (Kategori I) ve düşük aktif (Kategori II) grup arasında yapılmış olup, bu gruplar arasında fiziksel daha iyi olma haliyle ilgili istatistiksel olarak anlamlı farklar gözlenmiştir.

Çalışmamızda da elde edilen bulgular neticesinde menopoz süresinin ve yaşın artmasının özellikle belkalça oranı ölçümündeki artışla ve toplam yağsız kitledeki düşüşle ilgili olduğu görülmüştür. Yapılan bir çalışmada, postmenopozal kadınlarda BKİ ve diğer karıştırıcı faktörler kontrol edildikten sonra bile, premenopozal kadınlara kıyasla santral obezite gelişme olasılığının beş kat daha fazla olduğu tespit edilmiştir (22). Çalışmalar, kadınların yaşamının bu döneminde, kilo artışı ve santral obezitenin özellikle kardiyovasküler olaylar ve kanserler için daha yüksek risk oluşturduğunu doğrulamaktadı [23,24]. Benzer bir durum menopoz süresi için de geçerlidir. Katılımcıların menopoz süreleri arttıkça kilo ve bel-kalça oranlarında gözlemlenen artışa yağsız kitlede azalma eşlik etmiştir. Birçok çalışma, menopozdaki kadınların yaşam kalitesinin sadece hormon tedavisi ile değil, aynı zamanda diyet ve yașam tarzında ve düzenli fiziksel aktivitede değişiklikler yaparak artacağını göstermiştir [25]. Toplamda, ılımlı fiziksel aktiviteye sahip insanlar daha iyi genel sağlık ve sosyal işlevsellik seviyelerine sahiptir. Teoman ve 
arkadaşlarının çalışması, menopoz dönemindeki kadınlarda uyum ve yaşam kalitesinin altı haftalık bir egzersiz programının ardından dahi belirgin olarak iyileştiğini göstermektedir [26]. Menopozdaki kadınlarda fiziksel aktivitenin sadece fiziksel sağlığ değil, yaşam kalitesi ve özsaygıyı da geliştirebileceği bilinmektedir [27]. Kadınların yaşamlarının yaklaşık üçte birini menopoz döneminde geçirdiği düşünüldügüünde rutin egzersiz programlarının fiziksel, psikolojik ve sosyal yaşam kalitesi üzerinde olumlu etki yaratacağı ortadadır. Çalışma bulguları, sigara içenlerin ve içmeyenlerin ortalama egzersiz seviyelerindeki farklılıklar dikkate alındıktan sonra bile, sigara içenlerin içmeyenlere göre daha düşük fiziksel dayanıklılığa sahip olacağını göstermektedir. Sigara içenlere, fiziksel zindeliği iyileştirme çabalarının bir parçası olarak sigarayı bırakmaları için güçlü bir teşvik sağlanmalıdır [28]. Heydari ve arkadaşlarına ait bir çalışma sigara içmenin fiziksel hareketsizlik ile yakın bir ilişki içinde olduğunu ve sigara içenlerin sigara içmeyenlere göre daha az egzersiz yapma eğiliminde olduğunu göstermiştir [29].

\section{Sonuc}

Fiziksel aktivite ve egzersizin sağlık yararları açıktır; tüm yaş grupları fiziksel olarak daha aktif olmaktan fayda görür. Düzenli fiziksel aktivite, kadınlarda kardiyovasküler hastalıklarda \%12-40 oranında azalmaya yol açar [30]. Yürüyüş, bahçe işleri veya hafif sporlar gibi 1lımlı aktivitelerin dahi olumlu etkileri olduğu görülmektedir. Çoğu uluslararası kılavuz, haftada 150 dakika orta yoğunlukta fiziksel aktivite hedefi önermektedir [31]. Orta yoğunluktaki faaliyetler, birincil korunma için temel bir tavsiye niteliğindedir. Birincil korumada, düzenli fiziksel aktivitenin geliştirilmesinin ötesinde, birincil hastalık önleme, diyet kalıpları, kilo kontrolü ve sigara içmekten kaçınmak gibi sağlıklı yaşam alışkanlıklarının benimsenmesi de gereklidir. Menopoz sonrası hormon kullanımının kalp hastalıklarına karşı korunmasındaki başarısızlığının 1şığında, menopoz sonrası sağlığın korunmasında egzersizin rolünü yeniden düşünmek önem kazanmaktadır [32]. Çalışmamızda da gösterdiğimiz üzere menopoz süresi veya yaşın bir önemi olmaksızın fiziksel aktivitenin hayata entegre edilmesi düşük bel çevresi, yağ kitlesi, yağ yüzdesi ve yağsız kitlede artış ile karakterizedir.

\section{Referanslar}

1. Sander, M, Oxlund, B, Jespersen, A, Krasnik,, A, Mortensen E.L, Westendorp, R.G.J, et al. The challenges of human population ageing. Age Ageing, 2015, 1, 44(2):185-7.

2. Messier V, Rabasa-Lhoret R, Barbat-Artigas S, Elisha B, Karelis A.D, Aubertin-Leheudre M. Menopause and sarcopenia: A potential role for sex hormones, Vol. 68, Maturitas. Elsevier Ireland Ltd; 2011, pp 331-6.

3. Santoro, N, Epperson, C.N, Mathews, S.B, Menopausal symptoms and their management. Vol. 44, Endocrinology and Metabolism Clinics of North America, W.B. Saunders; 2015, pp 497-515.

4. Nikpour, S, Haghani, H, The effect of exercise on quality of life in postmenopausal women referred to the Bone densitometry centers of Iran University of Medical Sciences, Journal of Midlife Health, 2014 5(4), 174.

5. Beaufrère, B, Morio, B, Fat and protein redistribution with aging Metabolic considerations, European Journal of Clinical Nutrition, 2000, 54, 48-53.
6. Avis, N.E, Ory, M, Matthews, K.A, Schocken, M, Bromberger, J, Colvin, A, Health-related quality of life in a multiethnic sample of middle-aged women: Study of women's health across the nation (SWAN), Medical Care, 2003, 41(11), 1262-76.

7. Taleghani, F, Karimain, J, Babazadeh, S, Mokarian, F, Tabatabaiyan, M, Samimi, M.A, et al., The effect of combined aerobic and resistance exercises on quality of life of women surviving breast cancer, Iranian Journal of Nursing and Midwifery Research, 2012, 17(1), 47-51.

8. Nielsen, S.T, Matheson, I, Rasmussen, J.N, Skinnemoen, K, Andrew, E, Hafsahl, G, Excretion of iohexol and metrizoate in human breast milk, Acta Radiology, 2008, 28(5), 523-6.

9. Nied, R.J, Franklin, B, Promoting and prescribing exercise for the elderly, American Family Physician, 2002, 65, 419-28.

10. Farrell, R.T, Gamelli, R.L, Aleem, R.F, Sinacore, J.M, The relationship of body mass index and functional outcomes in patients with acute burns, Journal of Burn Care \& Research : Official Publication of the American Burn Association, 2008, 29(1), 102-8.

11. Vogel, J.A, Friedl, K.E, Body Fat Assessment in Women: Special Considerations, Sports Medicine: An International Journal of Applied Medicine and Science in Sport and Exercise, 1992, 13, 24569

12. Kuczmarski, R.J, Flegal, K.M, Campbell, S.M, Johnson, C.L, Increasing Prevalence of Overweight Among US Adults: The National Health and Nutrition Examination Surveys, 1960 to 1991, Journal of American Medicine Association, 1994, 20, 272(3), 20511

13. Ricciardi, R, Talbot, L.A, Use of bioelectrical impedance analysis in the evaluation, treatment, and prevention of overweight and obesity, Journal of the American Academy of Nurse Practitioners, 2007, 19(5), 235-41.

14. Saglam, M, Arikan, H, Savci, S, Inal-Ince,, D, Bosnak-Guclu M, Karabulut, E, et al, International physical activity questionnaire: Reliability and validity of the Turkish version, Perceptual and Motor Skills, 2010,111(1):278-84

15. Ara, A, Guidelines for Data Processing and Analysis of the International Physical Activity Questionnaire (IPAQ) - Short and Long Forms Contents.

16. Compston, J.E, Watts, N.B, Chapurlat, R, Cooper, C, Boonen, S, Greenspan, S, et al., Obesity is not protective against fracture in postmenopausal women: Glow, The American Journal of Medicine, 2011, 124(11), 1043-50.

17. Algün, E, Menopoz, Turkiye Klinikleri Endocrinoloji Dergisi, 2003, 1(2), 127-32.

18. Field, A, Discovering statistics using IBM SPSS Statistics, 5th ed. London, 2018, pp111

19. Lambrinoudaki, I, Brincat, M, Erel, C.T, Gambacciani, M, Moen, M.H, Schenck-Gustafsson, K, et al. EMAS position statement: Managing obese postmenopausal women, Maturitas, 2010, 66(3), 323-6.

20. Key, T.J, Appleby, P.N, Reeves, G.K, Roddam, A, Dorgan, J.F, Longcope, C, et al. Body mass index, serum sex hormones, and breast cancer risk in postmenopausal women, Journal of National Cancer Institute, 2003, 20, 95(16), 1218-26.

21. DiPietro, L, Physical activity, body weight, and adiposity: An epidemiologic perspective, Exercise and Sport Sciences Reviev, 1995, 23(1), 275-303

22. Donato, G.B, Fuchs, S.C, Oppermann, K, Bastos, C, Spritzer, P.M Association between menopause status and central adiposity measured at different cutoffs of waist circumference and waist-to-hip ratio, Menopause, 2006, 13(2), 280-5.

23. Kozakowski, J, Gietka-Czernel, M, Leszczynska, D, Majos, A, Obesity in menopause - Our negligence or an unfortunate inevitability? Vol. 16, Przeglad Menopauzalny. Termedia Publishing House Ltd, 2017, pp 61-5.

24. Gravena, A.A.F, Brischiliari, S.C.R, Lopes, T.C.R, Agnolo, C.M.D Carvalho, M.D.B, Pelloso, S.M, Excess weight and abdominal obesity in postmenopausal Brazilian women: A population-based study, BMC Womens Health, 2013, 14, 13(1), 46.

25. Bosch, X, Spain focuses on quality of life during menopaus, Lancet 2000, 355(9202), 478

26. Teoman, N, Özcan, A, Acar, B, The effect of exercise on physical fitness and quality of life in postmenopausal women, Maturitas, 2004, 20, 47(1), 71-7. 
27. Elavsky, S, Physical activity, menopause, and quality of life: The role of affect and self-worth across time, Menopause, 2009, 16(2), 26571

28. Conway, T.L, Cronan, T.A, Smoking, exercise, and physical fitness, Preventive Medicine, 1992, 21(6), 723-34.

29. Heydari, G, Hosseini, M, Yousefifard, M, Asady, H, Baikpour, M, Barat, A, Smoking and physical activity in healthy adults: A crosssectional study in Tehran, Tanaffos, 2015, 14(4), 238-45.

30. Rivet, C, What type of exercise prevents cardiovascular disease in postmenopausal women? Canadian Medical Association Journal, 2003, 168(3), 314.

31. Zapantis, G, Santoro, N, The menopausal transition: Characteristics and management, Vol. 17, Best Practice and Research: Clinica Endocrinology and Metabolism, Bailliere Tindall Ltd, 2003, pp 33 52

32. Beitz, R, Dören, M, Physical activity and postmenopausal health, Journal of the British Menopause Society, 2004, 10, 70-4.

http://edergi.cbu.edu.tr/ojs/index.php/cbusbed isimli yazarın CBU-SBED başlıklı eseri bu Creative Commons Alıntı-Gayriticari4.0 Uluslararası Lisansı ile lisanslanmıştır

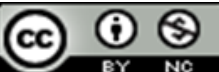

